\title{
Perencanaan Pembangkit Listrik Tenaga Surya Hybrid Pada Area Parkir Gedung Dinas Cipta Karya, Dinas Bina Marga Dan Pengairan Kabupaten Badung
}

\author{
Eric Timotius Abit Duka ${ }^{1}$, I Nyoman Setiawan ${ }^{2}$, Antonius Ibi Weking ${ }^{3}$ \\ ${ }^{12}{ }^{3}$ Program Studi Teknik Elektro, Fakultas Teknik, Universitas Udayana \\ email : timotius.abit@gmail.com ${ }^{1}$, setiawan@unud.ac.id ${ }^{2}$, tony@ee.unud.ac.id ${ }^{3}$
}

\begin{abstract}
Abstrak
Meningkatnya kebutuhan energi listrik di Bali mengharuskan penambahan pasokan energi listrik, sedangkan energi konvensional seperti minyak bumi, batubara dan gas alam terus dipergunakan. Oleh karena itu, pemanfaatan energi non konvensional harus ditingkatkan seperti energi surya. Salah satu penyediaan energi listrik non konvensional yang siap dipergunakan secara masal adalah menggunakan sistem teknologi PLTS Fotovoltaik. Analisis data di dalam studi ini menggunakan metode perhitungan manual untuk menghitung kebutuhan daya listrik, menetapkan daya yang akan dibangkitkan, menghitung jumlah serta kapasitas modul surya dan inverter, menghitung sudut kemiringan dan lokasi modul surya. PLTS menggunakan sistem hybrid dengan PLN, bekerja secara otomatis yang akan diatur oleh sistem kontrol inverter. PLTS berkapasitas 148,274 kW mensuplai 30\% dari konsumsi energi listrik pada gedung sebesar 2,310 MWh.
\end{abstract}

Kata kunci: PLTS, Modul Surya, Inverter, Hybrid

\begin{abstract}
The increasing demand for electrical energy in Bali requires additional electrical energy supply, while conventional energy such as petroleum, coal and natural gas continue to be used. Therefore, the utilization of non-conventional energy like solar energy should be increased. One of provision of non-conventional electric energy which is ready to be widely used is using PLTS Photovoltaic technology. The data analysis in this study uses manual calculation method to calculate electric power requirement, setting the result for electrical power, calculating the amount and capacity for solar module and inverter, calculating slope angle and location of solar module. PLTS uses a hybrid system with PLN, which works automatically to be controlled by the inverter control system. PLTS capacity of $148,274 \mathrm{~kW}$ supply $30 \%$ of the electrical energy consumption in the building of 2,310 MWh.
\end{abstract}

Key words: PLTS, Solar Module, Inverter, Hybrid

\section{PENDAHULUAN}

Kebutuhan energi listrik di Bali yang tidak diikuti dengan penambahan pasokan energi listrik akan menimbulkan keterbatasan hingga kekurangan pasokan listrik. Oleh karenanya, pemanfaatan energi non konvensional seperti energi surya harus dikembangkan sebagai upaya pengembangan sistem penyediaan energi listrik di Bali [1]. Pulau Bali terletak di sepanjang garis khatulistiwa yang mendapatkan sinar matahari sepanjang tahun, sehingga secara teknis Pulau Bali sangat berpotensial untuk pengembangan energi surya. Penyediaan energi listrik alternatif yang siap dipergunakan secara masal pada saat ini salah satunya adalah menggunakan sistem teknologi PLTS Fotovoltaik [2].

Adanya pembangkit listrik alternative terbarukan di Bali merupakan bagian dari upaya menjadikan Bali sebagai kawasan proyek percontohan pengembangan energi bersih dan terbarukan Kementrian Energi dan Suber Daya Mineral [3]. Demikian juga dengan apa yang diupayakan oleh pemerintah Bali untuk menjadikan Bali sebagai "Green Province" atau Provinsi Hijau [4]. Selain itu seluruh pemerintah kabupaten di Bali juga perlu mendorong pengembangan energi terbarukan dalam hal ini Pemerintah Kabupaten Badung. Oleh sebab itu, perencanaan pembangunan PLTS pada area parkir gedung Dinas Cipta Karya, Dinas Bina 
Marga, dan Pengairan Kabupaten Badung diharapkan dapat menghemat energi listrik dari PLN pada gedung tersebut. Perencanaan PLTS pada area parkir gedung Dinas Cipta Karya, Dinas Bina Marga, dan Pengairan Kabupaten Badung bekerja secara hybrid dengan PLN.

\section{KAJIAN PUSTAKA}

\subsection{Pembangkit Tenaga Listrik}

Pembangkit tenaga listrik merupakan salah satu peralatan yang berfungsi untuk memproduksi tenaga listrik dengan cara mengubah energi potensial menjadi tenaga mekanik selanjutnya menjadi tenaga listrik..

\subsection{Perencanaan Sistem Tenaga Listrik}

Perencanaan pengembangan sistem tenaga listrik diperlukan prakiraan kebutuhan tenaga listrik yang dapat memberikan informasi kepada pembuat kebijakan sehingga dengan prakiraan yang baik akan dapat mengurangi resiko pembangunan yang tidak dibutuhkan. Dalam prakiraan kebutuhan tenaga listrik pada suatu daerah tergantung dari data yang mencakup perkembangan daerah tersebut seperti letak daerah, jumlah penduduk, standar kehidupan, rencana pembangunan atau pengembangan daerah di masa yang akan datang.

\subsection{Potensi Energi Surya Untuk Pengembangan PLTS di Indonesia}

Indonesia merupakan negara beriklim tropis yang mempunyai potensi energi surya cukup besar. Berdasarkan data intensitas radiasi matahari di Indonesia diperoleh data dengan distribusi di Kawasan Barat Indonesia (KBI) sekitar 4,5 kWh/m²/hari dan di Kawasan Timur Indonesia (KTI) sekitar $5,1 \mathrm{kWh} / \mathrm{m}^{2} / \mathrm{hari}$. Dengan demikian, potensi intensitas radiasi matahari rata-rata di Indonesia yaitu sebesar $4,8 \mathrm{kWh} / \mathrm{m}^{2} /$ hari [2].

\subsection{PLTS}

PLTS adalah suatu teknologi pembangkit yang akan mengkonversikan energi foton dari surya menjadi energi listrik. Konversi ini terjadi pada PV modul yang terdiri dari sel surya, sel surya merupakan lapisanlapisan tipis dari silicon (Si) murni dan bahan semi kondukator lainnya. Apabila bahan tersebut mendapat energi foton, akan mengeksitasi elektron dari ikatan atomnya menjadi elektron yang bergerak bebas dan akhirnya akan mengeluarkan tegangan listrik arus searah. PLTS secara garis besar diklasikfikasikan menjadi dua berdasarkan aplikasi dan konfigurasinya, di antaranya: sistem PLTS yang tidak terhubung dengan jaringan (off-grid PV plant), atau yang lebih dikenal dengan sebutan PLTS berdiri sendiri (stand alone) dan sistem PLTS terhubung dengan jaringan (on-grid PV plant) atau lebih dikenal dengan sebutan PLTS gridconnected.

\subsection{Menghitung Kapasitas PLTS}

Persamaan menghitung area array PLTS adalah sebagai berikut [5].

$$
\text { PV Area }=\frac{E_{L}}{G_{a v} \times \eta_{P V} \times T C F \times \eta_{O u t}}
$$

Keterangan :

$E_{L}$ adalah pemakaian energi ( $\left.k W h / h a r i\right)$.

Gav adalah insolasi harian matahari rata-rata (kWh/m2/hari)

Пpv adalah efisiensi panel surya.

TCF adalah Temperature correction factor.

$\eta$ out adalah efisiensi inverter.

Persamaan menghitung daya yang akan dibangkitkan oleh PLTS adalah sebagai berikut.

$\mathrm{P}$ Watt Peak $=$ Area array $x$ PSI $x \eta p v$

Keterangan :

PSI (Peak Solar Insolation) adalah 1000w/m2 Пpv adalah efisiensi panel surya

Selanjutnya berdasarkan besar daya yang akan dibangkitkan, maka jumlah panel surya yang diperlukan diperhitungkan dengan rumus sebagai berikut:

$$
\text { Jumlah Panel Surya }=\frac{P(\text { Watt Peak })}{P m p p}
$$

Keterangan :

$\mathrm{P}$ watt Peak adalah Daya yang dibangkitkan (WP)

PMPP adalah Daya maksimum keluaran panel surya

\subsection{Orientasi PV Modul}

PV modul hanya akan efektif bila mendapat sinar langsung dengan arah normal tegak lurus terhadap permukaan PV modul. Jika semakin jauh sudut tegak PV modul terhadap matahari maka tingkat penerimaan sinar matahari akan semakin rendah karena bila sudut PV modul semakin miring maka sebagian besar sinar matahari akan memantul dari permukaan sel surya dan hanya sedikit foton yang diserap. Persamaan untuk mengetahui ketinggian maksimum 
(dalam derajat) ketika matahari mencapai langit $(\alpha)$, secara mudah sebagai berikut [6].

$$
\begin{array}{r}
\alpha=90^{\circ}-\text { lat }+\delta(N \text { hemisphere }) \\
90^{\circ}+\text { lat }-\delta(S \text { hemisphere })
\end{array}
$$

Keterangan :

lat adalah garis lintang (latitude) lokasi instalasi PV modulterpasang (dalam satuan derajat)

$\delta$ adalah sudut dari deklinasi matahari $[23,450]$

Sedangkan sudut yang harus dibentuk oleh PV modul terhadap permukaan bumi $(\beta)$, dapat diperoleh dengan

$\beta=90^{\circ}-\alpha$

\subsection{Inverter}

Inverter berfungsi untuk merubah arus dan tegangan listrik DC (direct current) yang dihasilkan PV array menjadi arus dan tegangan listrik AC (alternating current) dengan frekuensi $50 \mathrm{~Hz} / 60 \mathrm{~Hz}$. Pemilihan inverter yang tepat untuk aplikasi tertentu, tergantung pada kebutuhan beban dan tergantung pada apakah inverter akan menjadi bagian dari sistem yang terhubung ke jaringan listrik atau sistem yang berdiri sendiri. Berdasarkan bentuk gelombang yang dihasilkan, inverter di kelompokan menjadi tiga yaitu square wave, modified sine wave, true sine wave [7].

\section{METODE PENELITIAN \\ 3.1 Gambaran Umum Sistem}

Identifikasi gedung Dinas Cipta Karya,

Dinas Bina Marga, dan Pengairan Kabupaten

Badung untuk mengetahui peralatan listrik yang dipergunakan dan sistem instalasi listrik pada setiap ruangan serta letak geografis lokasi penelitian dengan cara mengumpulkan data dan dokumentasi yang terdapat dilokasi penelitian. Metode penelitian yang dilakukan sebagai berikut:

1. Mengumpulkan data-data sebagai pendukung penelitian meliputi data identifikasi peralatan listrik, data sistem instalasi gedung, data AMR pada gedung, data intensitas radiasi matahari, data kenaikan suhu udara di Mengwi Badung, data spesifikasi komponen PLTS yang digunakan dan data gambar denah area parkir gedung.

2. Menetapkan besarnya daya yang akan dibangkitkan PLTS dengan menghitung area string dan menghitung besar pemakaian energi listrik pada gedung.

3. Menghitung jumlah panel surya yang akan digunakan, memilih jenis produk panel surya dan menghitung jumlah panel surya berdasarkan spesifikasi.

4. Menetapkan kapasitas inverter yang digunakan dengan menghitung nilai Pmpp dan memilih jenis produk inverter.

5. Menetapkan susunan panel surya, meninjau letak panel surya, menghitung nilai ketinggian maksimum matahari dan menentukan kemiringan PV modul.

\section{HASIL DAN PEMBAHASAN \\ 4.1 Gambaran Umum Gedung}

Gedung Dinas Cipta Karya, Dinas

Bina Marga, dan Pengairan Kabupaten Badung terletak di Jalan Raya Sempidi No.43, Sempidi, Wengwi. Gedung ini memiliki 3 lantai yang difungsikan sebagai ruang office dan basement yang difungsikan sebagai area parkir. Gedung ini memulai kegiatan pada hari kerja dari pukul 07.30 Wita hingga 15.30 Wita, gedung ini beroperasi 5 hari dalam seminggu.

\subsection{Profil Energi Listrik Gedung}

Penentuan beban total harian pada gedung merupakan langkah awal perancangan sistem PLTS. Kurva beban listrik harian gedung Dinas Cipta Karya, Dinas Bina Marga, dan Pengairan Kabupaten Badung akan didapatkan dari penentuan beban total harian tersebut.

Tabel 1. Data Konsumsi energi listrik gedung 7 September 2017 


\begin{tabular}{|c|c|}
\hline September 7, 2017 & Baban Puncak (watt) \\
\hline 12:00 AM & $6.367,01$ \\
\hline 1:00 AM & $6.383,5$ \\
\hline 2:00 AM & $6.486,47$ \\
\hline 3:00 AM & $6.579,12$ \\
\hline 4:00 AM & $6.788,78$ \\
\hline 5:00 AM & $6.838,83$ \\
\hline 6:00 AM & $6.848,25$ \\
\hline 7:00 AM & $6.855,55$ \\
\hline 8:00 AM & $200.177,32$ \\
\hline 9:00 AM & $235.736,41$ \\
\hline 10:00 AM & $238.145,15$ \\
\hline 11:00 AM & $249.912,13$ \\
\hline 12:00 PM & $237.177,07$ \\
\hline 1:00 PM & $235.523,34$ \\
\hline 2:00 PM & $236.647,31$ \\
\hline 3:00 PM & $235.507,26$ \\
\hline 4:00 PM & $220.007,28$ \\
\hline 5:00 PM & $129.771,2$ \\
\hline 6:00 PM & $6.761,57$ \\
\hline 7:00 PM & $6.568,77$ \\
\hline 8:00 PM & $6.540,56$ \\
\hline 9:00 PM & $6.455,89$ \\
\hline 10:00 PM & $6.410,2$ \\
\hline 11:00 PM & $6.362,5$ \\
\hline Total Konsumsi Energi & $2.310 .401,47 \mathrm{Wh}$ \\
\hline
\end{tabular}

Berdasarkan hasil pengukuran energi listrik gedung dari AMR dalam rentang waktu 3 bulan yaitu dari tanggal 1 Agustus 2017 hingga 31 Oktober 2017, menunjukkan bahwa pemakaian energi listrik tertinggi di gedung pada tanggal 7 September 2017 sebesar 249,912 kWh. Data AMR digunakan sebagai acuan perhitungan rancangan PLTS karena data AMR menunjukan beban puncak sesungguhnya pada gedung tersebut.

\subsection{Perhitungan Kapasitas PLTS}

Menghitung area string dan menghitung energi listrik yang akan di suplai dari PLTS didapat dengan menghitung luas area string sebagai berikut.

$$
\text { PV Area }=\frac{E_{L}}{G_{a v} \times \eta_{P V} x T C F \times \eta_{\text {out }}}
$$

$$
\text { PV Area }=\frac{2.310,401 \mathrm{kWh}}{4,84 K w h / m^{2} \times 0,12 \times 0,98 \times 0,99}
$$

$$
\text { PV Area }=4.100,14 \mathrm{~m} 2
$$

Berdasarkan perhitungan $\mathrm{PV}$ area maka didapatkan nilai sebesar $4.100,14 \mathrm{~m}^{2}$, nilai tersebut merupakan luas area PV yang dibutuhkan untuk membangkitkan kebutuhan energi $\left(E_{L}\right)$. Namun, luas ini akan disesuaikan dengan luasan lokasi penempatan panel surya yang hanya sebesar $1.230,04 \mathrm{~m}^{2}$ maka luasan PLTS yang bisa dipasang sebesar $30 \%$ dari konsumsi energi listrik gedung tersebut.

Berdasarkan hasil perhitungan luas PV area, maka daya yang akan dibangkitkan dapat dihitung sebagai berikut.

$$
\begin{gathered}
P \text { Watt Peak }=1230,04 \mathrm{~m}^{2} \times 1000 \mathrm{~W} / \mathrm{m}^{2} \times 0,12 \\
P \text { Watt Peak }=147,604 \mathrm{kWp}
\end{gathered}
$$

\subsection{Kapasitas Komponen PLTS}

Hal yang terpenting ialah pemilihan tipe komponen, mengingat banyaknya tipe produk di pasaran. Pemilihan tipe produk didasari oleh beberapa hal yaitu keterjangkauan barang terhadap konsumen, pertimbangan nilai ekonomis, dan pelayanan yang berkelanjutan. PLTS pada gedung Dinas Cipta Karya, Dinas Bina Marga, dan Pengairan Kabupaten Badung akan menggunakan panel surya dengan kapasitas 150wp produksi BP Solar pollycrystaline.

Kebutuhan jumlah panel surya dapat ditentukan sebagai berikut.

$$
\begin{gathered}
\text { Jumlah Panel Surya }=\frac{P(\text { Watt Peak })}{\text { Pmpp }(\text { Watt Peak })} \\
\text { Jumlah Panel Surya }=\frac{147.604,8}{150} \\
\text { Jumlah Panel Surya }=985 \text { panel }
\end{gathered}
$$

Jumlah panel surya yang dibutuhkan ialah sebanyak 985 panel yang nantinya akan dibagi menjadi 4 string dengan masingmasing string akan berisikan 247 panel yang akan disusun secara seri dan paralel. 


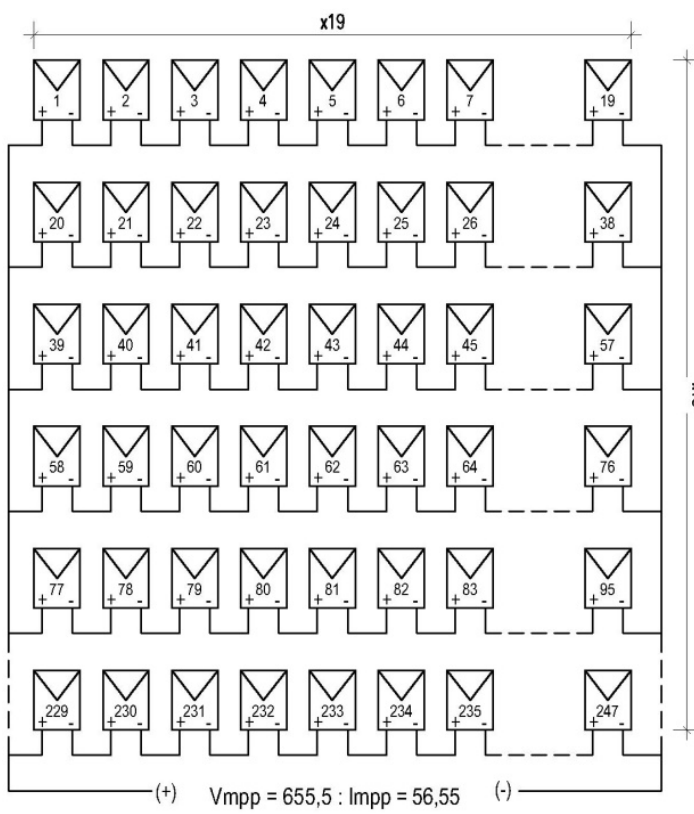

Gambar 4.1 Susunan panel menjadi 1 string

Berdasakan spesifikasi panel surya $\mathrm{V}_{\mathrm{mp}}=34,5 \mathrm{~V}, \mathrm{I}_{\mathrm{mp}}=4,35 \mathrm{~A}$ dan $\mathrm{P}_{\mathrm{MPP}}=150 \mathrm{Wp}$ per panel surya, maka dengan spesifikasi tersebut maka besar $V_{m p}, I_{m p}$ dan $P_{M P P}$ pada 1 panel dapat dihitung sebagai berikut: $V_{m p} 1$ panel adalah $34,5 \times 19=655,5 \mathrm{~V}, \mathrm{I}_{\mathrm{mp}} 1$ panel adalah 4,35 x $13=56,55 \mathrm{~A}$, maka $\mathrm{P}_{\mathrm{MPP}}$ dapat dicari sebagai berikut.

$$
\begin{aligned}
& P_{M P P}=V_{m p} \times I_{m p} \\
& P_{M P P}=655,5 \mathrm{~V} \times 56,5 \mathrm{~A} \\
& =37,068 \mathrm{kWp}
\end{aligned}
$$

Berdasarkan gambar rangkaian di atas makan jumlah panel surya yang akan digunakan adalah sebanyak 988 panel surya dengan tiap string akan menghasilkan daya sebesar 37,068 kWp, jika 4 string disusun maka total daya yang dihasilkan PLTS sebesar 148,274 kWp.

\subsection{Perhitungan Kemiringan PV String}

Pada proses instalasi PLTS memerlukan ketelitian dalam menentuan sudut kemiringan panel surya, hal ini diperlukan supaya panel surya mendapatkan pancaran sinar matahari yang optimal pada kawasan Pusat Pemerintahan Kabupaten Badung. Orientasi dan inklinasi/kemiringan panel surya pada lokasi Jalan Raya Sempidi, Mengwi (8,60 LS, 115,18 BT)[8] adalah sebagai berikut:

$$
\begin{aligned}
& \alpha=900+\text { lat }-\delta \\
& =90^{\circ}+8,60^{\circ}-24,35^{\circ} \\
& =75,15^{\circ} \\
& \beta=900+\alpha \\
& =90^{\circ}-75,15^{\circ} \\
& =14,85^{\circ}
\end{aligned}
$$

Jadi sudut kemiringan panel surya maksimum adalah sebesar $14,85^{\circ}$.

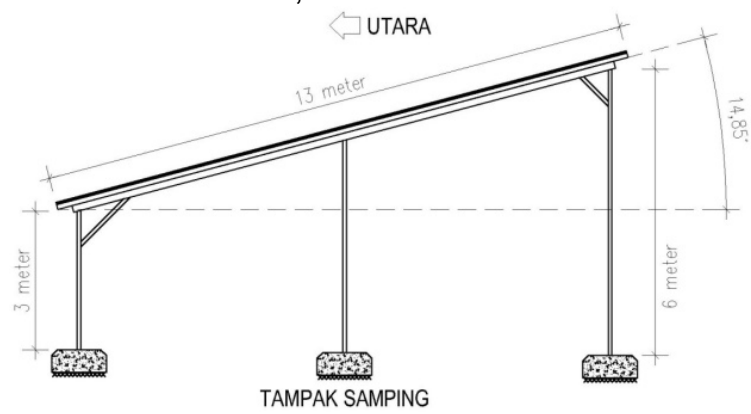

Gambar 4.2 Struktur kemirigan panel surya

Terlihat struktur kemiringan panel surya akan menghadap ke utara, dengan derajat kemiringan $14,85^{\circ}$.

\subsection{Rancangan Sistem Dan Lokasi PLTS}




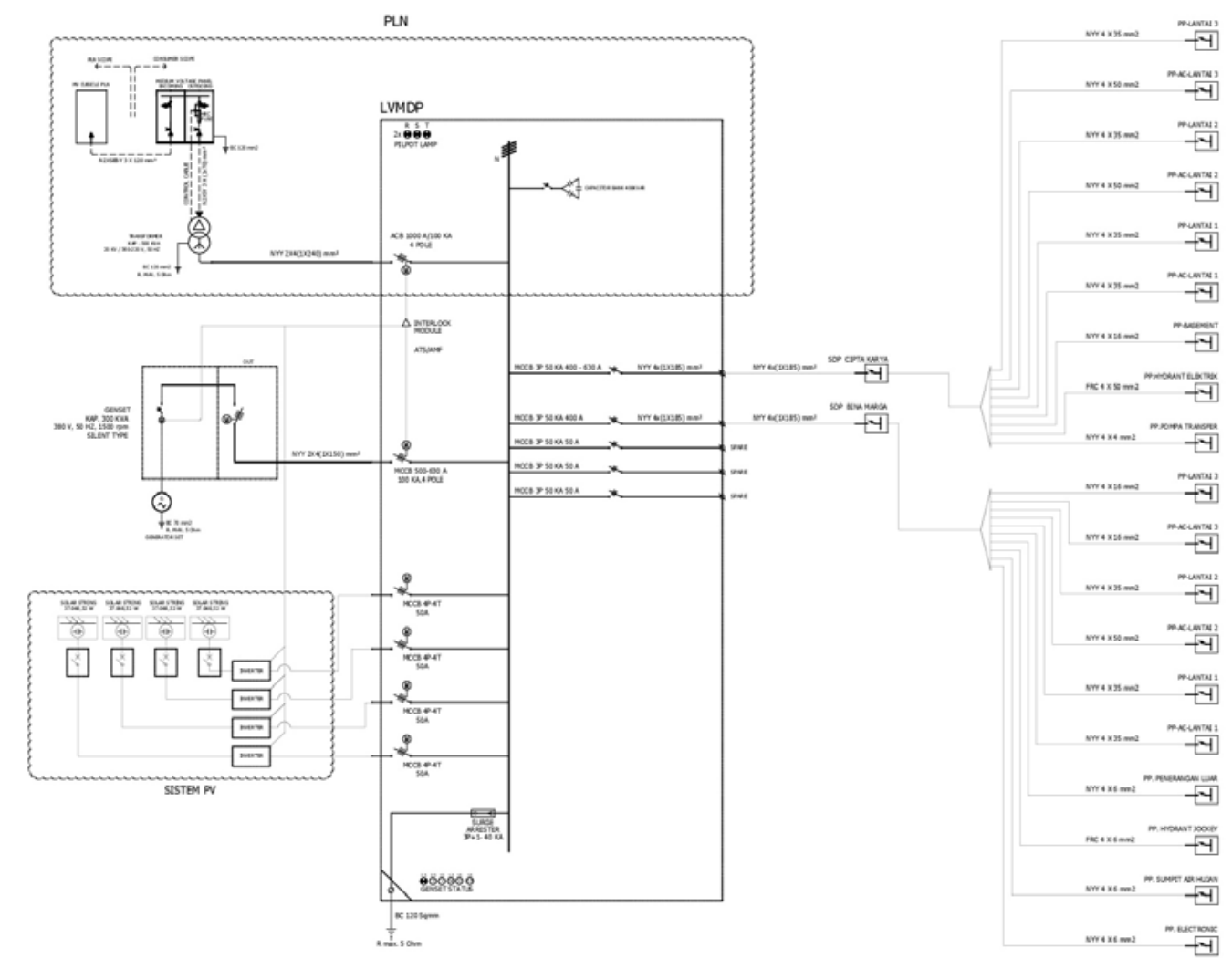

Gambar 4.3 Rancangan single line diagram PLTS

Gedung Dinas Cipta Karya, Dinas

Bina Marga, dan Pengairan Kabupaten Badung nantinya akan memiliki 3 sumber listrik yaitu sumber dari PLN, Generator dan PLTS hal tersebut akan menyebabkan gedung ini menggunakan sistem hybrid. Sistem hybrid ini akan menggabungkan 2 sumber pembangkit yang ada menjadi lebih efisien dalam penggunaanya yang akan di atur oleh Inverter HITC three-phase hybrid 50 KW yang sudah tersedia sistem hybrid pada perangkat tersebut. Sumber listrik dari PLN akan mensuplai $100 \%$ jika sistem pada PLTS mengalami gangguan, sumber listrik yang dihasilkan oleh PLTS akan mensuplai 30\% dari kebutuhan gedung berdasarkan data AMR. Kelebihan beban yang melebihi kapasitas dari PLTS akan langsung dipenuhi oleh salah satu pembangkit yang tersedia ( PLN dan Generator) dan sumber listrik dari generator akan bekerja 100\% apabila kedua sumber listrik lainnya tidak dapat bekerja.

Pemilihan lokasi ini berdasarkan pertimbangan agar panel surya menghadap ke utara dengan sudut kemiringan $14,85^{\circ}$ serta dekat dengan ruang instalasi gedung.

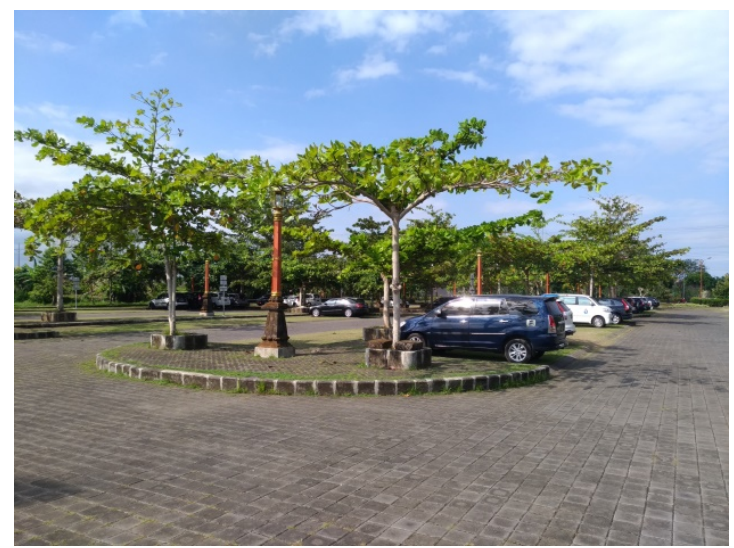

Gambar 4.4 Lokasi perencanaan penempatan panel surya

Lokasi perencanaan penempatan panel surya ini mencakupi kebutuhan besarnya luas area PV yang sebesar $1230,04 \mathrm{~m}^{2}$.

\section{PENUTUP}

Area parkir gedung Dinas Cipta Karya, Dinas Bina Marga, dan Pengairan Kabupaten Badung rencanakan PLTS dengan kapasitas 148,274 kW yang akan mensuplai $30 \%$ dari konsumsi energi listrik pada gedung 
sebesar 2,310 MWh. PLTS akan bekerja secara hybrid dengan sistem PLN. Perlu dilakukan penelitian lebih lanjut terhadap pemanfaatan PLTS pada area parkir gedung Dinas Cipta Karya, Dinas Bina Marga, dan Pengairan Kabupaten Badung diantaranya: Pemanfaatan baterai sebagai media penyimpanan energi, sehingga PLTS dapat digunakan pada malam hari atau saat cuaca mendung serta dilakukan kajian investasi pada design PLTS ini agar mengetahui keuntungan nilai ekonomis di masa depan.

\section{DAFTAR PUSTAKA}

[1] Indrajaya, Mansyur. 2012. Studi Komparatif 2 Model Pembangkit Listrik Sistem Hibrid PLTS dan PLN/Genset. Makasar: Fakultas Teknik Universitas Udayana

[2] Rahardjo, Amien dkk. 2008. Optimalisasi Pemanfaatan Sel Surya Pada Bangunan Komersial Secara Terintegrasi Sebagai Bangunan Hemat Energi. Depok: Fakultas Teknik Universitas Indonesia

[3] www.esdm.go.id diakses tanggal 29-Juni 2017

[4] www.baliprov.go.id diakses tanggal 29Juni 2017

[5] Nafeh, A.E.A. 2009. Design and economic Analiysis of a stand-alone PV System to Electrify a reamote area Household in Egypt. The Open Renewable Energy Journal 2 : 33-37

[6] ABB. 2010. Technical Application Papers N0.10 Photovoltaic Plants. Italy. Bergamo

[7] Gatot, A, I Wayan. 2014. Studi Terhadap Unjuk Kerja Pembangkit Listrik Tenaga Surya 1920 Watt di Universitas Udayana Bukit Jimbaran. Denpasar: Universitas Udayana

[8] www.maps.google.com diakses tanggal 3-November 2017 